\title{
ANALISIS PREFERENSI KETIDAKNYAMANAN KONSUMEN TERHADAP PROMOSI DAN PERSONAL SELLERYANG MEMPENGARUHI MINAT BELI KONSUMEN SERTA PEMILIHAN MEREK PADA ASURANSI (STUDI KASUS DI PT. PRUDENTIAL LIFE ASSURANCE)
}

\author{
Putu Dyah Permatha Korry ${ }^{1}$ \\ Ayu Wendy Widhia Pramesti ${ }^{2}$ \\ ${ }^{1}$ Fakultas Ekonomi dan Bisnis Universitas Pendidikan Nasional (Undiknas), Bali, \\ Indonesia \\ ${ }^{1}$ E-mail: mithakorry@gmail.com \\ E-mail: wendywidhia27@gmail.com
}

\begin{abstract}
ABSTRAK
Kesehatan merupakan hal penting yang harus diperhatikan dalam kehidupan seharihari, karena manusia tidak akan terlepas dari bahaya yang timbul secara tiba-tiba oleh suatu peristiwa. Asuransi merupakan salah satu cara untuk jaminan rasa aman dalam menangani risiko yang timbul secara tiba-tiba tersebut. Tak heran berbagai promosi dilakukan oleh perusahaan untuk menimbulkan minat beli konsumen, tetapi salah satu teknik promosi pemasaran langsung melalui telemarketing menimbulkan ketidaknyamanan, karena promosi melalui teknik ini konsumen merasa terganggu ketika dihubungi sebab menurut mereka telemarketer tidak memikirkan waktu yang tepat ketika menawarkan produk. Penjualan Pribadi (Personal Seller) merupakan agent asuransi dari perusahaan yang dapat berhubungan langsung dengan konsumen sehingga nantinya akan timbul minat beli akan asuransi. Untuk meningkatkan minat beli konsumen, ketidaknyamanan promosi, dan Personal Seller diharapkan dapat mempengaruhi konsumen sehingga setelah minat beli muncul, konsumen akan dapat memutuskan pemilihan merek pada asuransi. Data dikumpulkan melalui kuesioner kepada 85 responden. Teknik analisis data yang digunakan adalah persamaan struktural (SEM) dengan PLS. Hasil penelitian ini menunjukkan bahwa ketidaknyamanan promosi memiliki pengaruh negatif dan signifikan terhadap minat beli konsumen, sedangkan penjual pribadi memiliki pengaruh positif dan signifikan terhadap minat beli konsumen, dan minat beli konsumen memiliki pengaruh positif dan signifikan pada pemilihan merek. Berdasarkan hasil pengujian model Q2 mendapat nilai 0,774, yang menunjukkan model prediksi sesuai.
\end{abstract}

Kata Kunci: Ketidaknyamanan Promosi, Personal Seller, Minat Beli Konsumen, Pemilihan Merek pada Asuransi. 


\begin{abstract}
Health is an important thing to be noticed in everyday life, because humans will not be separated from the dangers that arise suddenly by an event. Insurance is one way to guarantee a sense of security in handling the risks that arise suddenly. No wonder various promotions are carried out by companies to generate consumer buying interest, but one of the promotional techniques of direct marketing through telemarketing is inconvenience, because promotion through this technique consumers feel disturbed when contacted because according to them telemarketers do not think of the right time when offering a product. Personal Sales (Personal Seller) is an insurance agent from a company that can deal directly with consumers so that later there will be buying interest in insurance. To increase consumer buying interest, promotional inconvenience, and seller personalities are expected to be able to influence consumers so that after buying interest arises, consumers will be able to decide on the brand selection on insurance. Data was collected through questionnaires to 85 respondents. The data analysis technique used is structural equation (SEM) with PLS. The results of this study indicate that promotional discomfort has a negative and significant effect on consumer buying interest, while a personal seller has a positive and significant effect on consumer buying interest, and consumer buying interest has a positive and significant effect on brand selection. Based on the results of testing the Q2 model gets a value of 0.774 , which shows the predicted model is appropriate.
\end{abstract}

\title{
Keywords :Inconvenience of Promotion, Personal Seller, Consumer Buying Interests, Brand Selection on Insurance.
}

\section{PENDAHULUAN}

\section{Latar Belakang Penelitian}

Kesehatan merupakan hal penting yang perlu di perhatikan oleh masyarakat saat ini, karena dalam kehidupan sehari-hari manusia tidak pernah terlepas dari yang namanya bahaya oleh peristiwa yang timbul secara mendadak. Baik itu menderita suatu penyakit, terjadinya kecelakaan, sampai dengan meninggal dunia. Maka dari itu manusia membutuhkan perlindungan, sehingga dapat hidup dengan aman dan nyaman ketika berada dirumah ataupun bepergian, dan disaat perekonomian di Indonesia mulai tidak stabil.Asuransi merupakan jaminan rasa aman yang dapat dipilih oleh masyarakat untuk kehidupan jangka panjang.

Pasar asuransi di Indonesia tidak semudah seperti di Negara maju yang mana penduduknya terkonsentrasi terhadap kesehatan dan jaminan yang dapat digunakan. Masyarakat di Indonesia masih kurang paham akan pentingnya berasuransi demi kelangsungan hidup jangka panjang mereka, sehingga asuransi bukan menjadi kebutuhan prioritas. Hal ini dikarenakan kurangnya informasi yang diterima oleh masyarakat mengenai 
asuransioleh perusahaan, sehingga ini menjadi suatu kendala yang dapat dihadapi perusahaan akan minat beli masyarakat yang masih rendah.

Sebagian masyarakat di Indonesia memiliki persepsi negatif mengenai asuransi, karena menurut mereka premi yang mereka bayarkan setiap bulannya tidak langsung dapat dirasakan manfaatnya, maka asuransi tergolong kedalam produk yang tidak begitu diminati oleh sebagian masyarakat tersebut. Selain itu promosi yang di lakukan oleh perusahaan yang dapat menimbulkan ketidaknyamanan bagi masyarakat saat ditawarkan produk tersebut, hal ini juga yang menjadikan masyarakat masih enggan untuk berasuransi.

Promosi setiap produk harus dapat mendorong minat beli pelanggan baru untuk membeli dan membeli ulang produk pada akhirnya. Penjualan pribadi (personal seller) merupakan upaya yang paling tepat yang memungkinkan pemasar untuk berfokus pada prospek penjualan yang paling menjanjikan, sehingga penjualan yang diinginkan pun bisa dicapai dan perusahaan bisa tumbuh dan berkembang.

Minat beli merupakan salah satu fase dalam proses pengambilan keputusan bagi konsumen yang timbul setelah adanya suatu kebutuhan yang dirasakan oleh individu. Pemilihan merek dalam memutuskan pembelian asuransi mengakibatkan calon nasabah yang ingin berasuransi akan lebih mempertimbangkan terlebih dahulu perusahaan asuransi mana yang akan dipilih untuk dijadikan sebagai jaminan hidup jangka panjang mereka. Oleh karena itu penulis tertarik untuk meneliti mengenai
Preferensi Mengenai

Ketidaknyamanan Konsumen

Terhadap Promosi dan Personal Seller Yang Mempengaruhi Minat Beli Konsumen Serta Pemilihan Merek Pada Asuransi (Studi Kasus di PT. Prudential Life Assurance)

\section{Kajian Literatur}

$\begin{array}{rr}\text { Berdasarkan } & \text { rumusan } \\ \text { masalah, tujuan penelitian, }\end{array}$ landasan teori yang telah diuraikan sebelumnya, kerangka pemikiran serta dari beberapa penelitian sebelumnya terkait dengan variabel - variabel yang diteliti dalam penelitian ini, sehingga dapat ditarik hipotesis sebagai berikut :

Menurut Julius R.

Latumaerissa (2011), asuransi merupakan suatu perjanjian dimana terdapat pihak tertanggung yang membayar premi kepada pihak penanggung guna mendapatkan penggantian karena suatu keinginan, kerusakan atau kehilangan keuntungan yang telah diharapkan yang kemungkinannnya tidak pasti akan terjadi di masa yang akan datang.

Promosi yang tepat akan meningkatkan minat beli konsumen terhadap produk tersebut. Jika promosi yang dilakukan oleh perusahaan melalui prosedur yang baik, tepat dan benar itu akan membuat konsumen merasa nyaman saat ditawarkan suatu produk tersebut sehingga nantinya akan mampu menarik minat beli konsumen akan produk tersebut, tetapi jika promosi yang dilakukan secara tidak transparan kepada calon konsumen, itu akan membuat calon konsumen merasa tidak nyaman dan akan menyebabkan minat beli akan produk tersebut 
menurun. Berdasarkan penelitian yang dilakukan terdahulu, maka untuk melihat pengaruh variable ketidaknyamanan promosi terhadap variable minat beli maka dapat disusun hipotesis sebagai beirkut :

H1 : Ketidaknyamanan promosi berpengaruh secara negative dan signifikan terhadap minat beli konsumen

Menurut Lee (2004) salah satu indikator promosi yakni, pemasaran langsung (direct marketing) terdapat teknik pemasaran melalui telemarketing yang memudahkan pihak perusahaan untuk menghubungi pelanggan kapan pun dan di mana pun. Sayangnya, kemudahan ini menimbulkan sejumlah ketidaknyamanan bagi calon pelanggan yang dihubungi oleh telemarketer. Telemarketer dari sebuah perusahaan dapat menghubungi calon pelanggan berkali-kali, terutama jika teleponnya tidak dijawab, sehingga calon pelanggan merasa terganggu. Ketika ditolak, Telemarketer bisa menghubungi lagi dengan nomor telepon seluler yang berbeda. Sehingga beberapa calon nasabah merasa terganggu dan merasa tidak nyaman akan promosi yang ditawarkan melalui teknik pemasaran tersebut.

Menurut Aryanto (2008), Personal Seller sangat berperan penting dalam membuat keputusan membeli, artinya bahwa Personal Seller harus mampu membuat konsumen tertarik terhadap produk/jasa yang diberikan. Semakin pintar Personal Seller dalam membujuk dan menjelaskan tentang produk/jasa, maka semakin konsumen percaya dan membeli produk/jasa yang ditawarkan. Personal Seller menjadi ujung tombak maju mundurnya perusahaan. Semakin handal Personal Seller meraih konsumen maka semakin maju perusahaan tersebut memperoleh keuntungan (Profit).Berdasarkan penelitian yang dilakukan terdahulu, maka untuk melihat pengaruh variable personall seller terhadap variable minat beli maka dapat disusun hipotesis sebagai beirkut :

H2 : personal seller berpengaruh secara positif dan signifikan terhadap minat beli konsumen

Para pemasar harus mendalami berbagai pengaruh mengenai pembelian konsumen dan mengembangkan pemahan mengenai bagaimana sebenarnya konsumen membuat keputusan pembelian mereka. Konsumen tidak langsung memutuskan membeli suatu produk, akan tetapi konsumen memiliki banyak pertimbanganpertimbangan yang pada akhirnya akan memutuskan membeli atau tidak produk tersebut.

Menurut Suwandari (2008), yang menjadi indikator minat beli seorang calon konsumen adalah sebagai berikut: Attention, yaitu perhatian calon konsumen terhadap produk yang ditawarkan oleh produsen. Interest, ketertarikan calon konsumen terhadap produk yang di tawarkan oleh produsen. Desire, keinginan calon konsumen untuk memiliki produk yang di tawarkan oleh produsen. Action, 
yaitu calon konsumen melakukan pembelian terhadap produk yang di tawarkan.

$\begin{array}{llr} & \text { Menurut Haaijer, et.al } \\ \text { (200:381), } & \text { konsumen } & \text { yang } \\ \text { mempunyai } & \text { pengalaman } & \text { yang }\end{array}$
positif terhadap suatu merek akan merespon lebih cepat terhadap pemilihan suatu merek. Hal ini terjadi karena konsumen tersebut akan mengingat kembali apa yang telah mereka rasakan dalam melakukan suatu preferensi. Pengalaman yang telah konsumen rasakan terhadap suatu merek akan sangat mempengaruhi preferensi. Berdasarkan penelitian yang dilakukan terdahulu, maka untuk melihat pengaruh variable minat beli terhadap variable Keputusan pemilihan merek maka dapat disusun hipotesis sebagai beirkut :

\section{H3 : Minat Beli berpengaruh secara positif dan signifikan terhadap Pemilihan Merek Asuransi}

\section{METODE}

\section{Desain Penelitian}

Jenis penelitian yang dilakukan dalam penelitian ini adalah penelitian kuantitatif. Menurut Sujarweni (2014: 39) jenis penelitian kuantitatif yaitu jenis penelitian yang menghasilkan penemuan-penemuan yang dapat dicapai dengan menggunakan prosedur-prosedur statistik atau cara-cara lain kuantifikasi (pengukuran).

\section{a. Populasi dan Sampel}

Populasi yang diambil dari penelitian yang dilakukan ini yakni masyarakat di Kota Denpasar yang meliputi wilayah Denpasar Utara, Denpasar Timur, Denpasar Selatan dan Denpasar Barat, dengan total masyarakat di Kota Denpasar sebesar 788.589 masyarakat.Penentuan jumlah sampel yang representative menurut Hair, et.al (2009) adalah tergantung pada jumlah indikator dikali 5 sampai 10. Jumlah sampel dalam penelitian ini, yakni 17 indikator dikali 5 memperoleh hasil 85 responden. Jadi dari keseluruhan populasi sampel yang diperlukan sejumlah 85 orang responden yang ada di Kota Denpasar.

\section{Teknik Pengumpulan Data}

Untuk memperoleh data yang diperlukan pada penelitian ini, peneliti menggunakan teknik pengumpulan data, yakni sebagai berikut :

1. Dokumentasi :Teknik dokumentasi pada penelitian ini yaitu dengan memanfaatkan dokumen-dokumen tertulis seperti data jumlah penjulan dari perusahaan.

2. Kuesioner :Kuesioner merupakan teknik pengumpulan data dimana partisipan atau responden mengisi pertanyaan atau pernyataan dari peneliti dan dengan menggunakan skla likert.

\section{Teknik Analisis Data}

Penelitian ini menggunakan teknik analisis jalur (path analysis). Dalam Riduwan dan Kuncoro (2014) path analysis digunakan untuk menganalisis bagaimana pola hubungan antar variabel dengan tujuan untuk mengetahui pengaruh langsung maupun tidak langsung variabel bebas (eksogen) terhadap variabel terikat (endogen). 
1. Pengukuran Model (Outer Model) :

Model pengukuran (outer model) digunakan untuk menilai validitas dan realibilitas model. Uji validitas dilakukan untuk mengetahui kemampuan instrumen penelitian mengukur apa yang seharusnya diukur (Sholihin \& Ratmono, 2013). Sedangkan uji reliablitas digunakan untuk mengukur konsistensi alat ukur dalam mengukur suatu konsep atau dapat juga digunakan untuk mengukur konsistensi responden dalam menjawab item pernyataan dalam kuesioner atau instrument penelitian.

Evaluasi Model Struktural (Inner Model)

Goodness of Fit untuk inner model dievaluasi dengan melihat persentase varian yang dijelaskan yaitu dengan melihat R2 (R-square variabel eksogen) untuk konstruk laten, mengukur seberapa nilai observasi dihasilkan oleh model dan juga estimasi parameternya. Nilai Qsquare $>0$ menunjukkan model memiliki predictive relevance, sebaliknya jika nilai Q-square < 0 menunjukkan model kurang memiliki predictive relevance. Perhitungan Qsquare dilakukan dengan rumus: $\mathrm{Q} 2=$ $1-(1-\mathrm{R} 12)(1-\mathrm{R} 22) \ldots(1-\mathrm{Rp} 2)$.

2. Uji Hipotesis

Menurut Hartono (2008) menjelaskan bahwa ukuran signifikansi keterdukungan hipotesis dapat digunakan perbandingan nilai T-table dan T-statistic. Jika T-statistic lebih tinggi dibandingkan nilai $T$ table, berarti hipotesis terdukung atau diterima. Dalam penelitian ini untuk tingkat keyakinan 5 persen (alpha 5 persen) maka nilai T-table untuk hipotesis satu (one-tailed) adalah $>1,96$.

\section{HASIL DAN PEMBAHASAN}

\section{Analisis Model Penelitian dengan Metode PLS (Partial Least Square).} Berdasarkan tahap-tahap pemodelan yang telah diuraikan sebelumnya maka model persamaan struktural penelitian ini dapat digambarkan sebagai berikut :

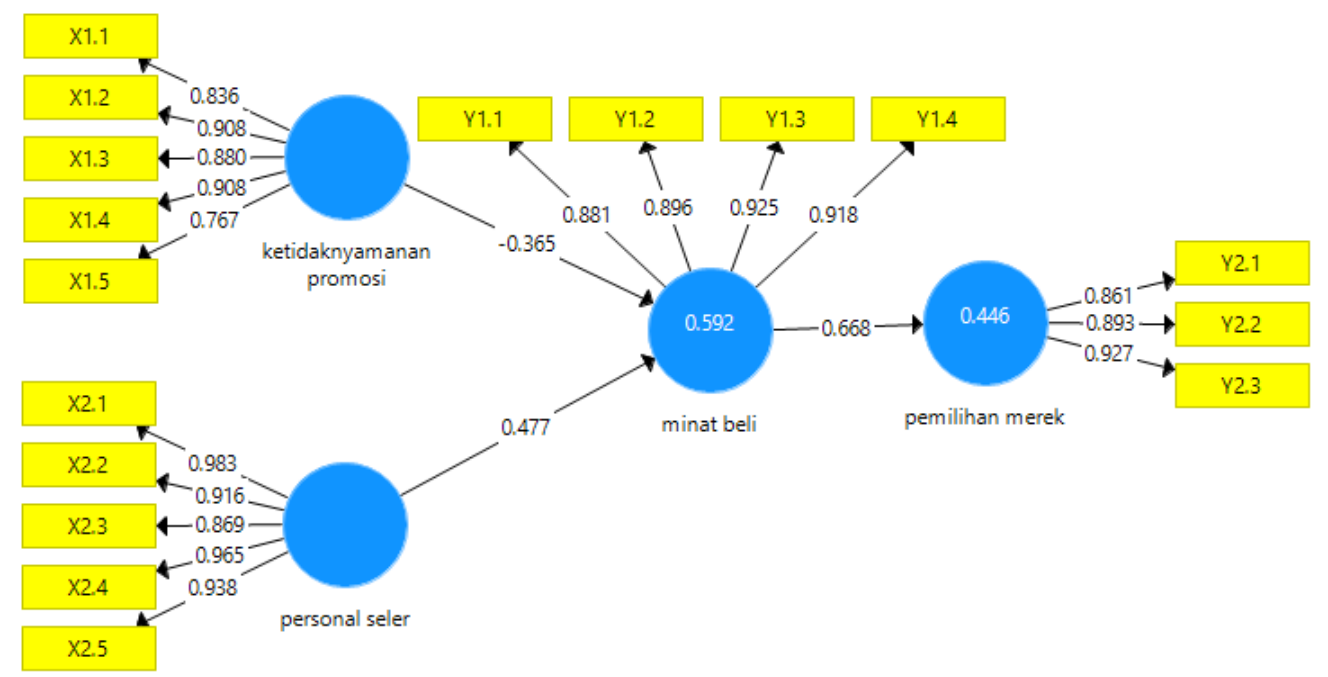




\section{Evaluasi Model Pengukuran atau Outer Model}

\section{Discriminant Validity dengan Menggunakan Cross Loading}

Cross Loading

\begin{tabular}{|l|r|r|r|r|}
\hline & $\begin{array}{l}\text { Ketidaknyamananprom } \\
\text { osi }\end{array}$ & $\begin{array}{l}\text { Minatbe } \\
\text { li }\end{array}$ & $\begin{array}{l}\text { Pemilihanmer } \\
\text { ek }\end{array}$ & $\begin{array}{l}\text { Person } \\
\text { al } \\
\text { Seller }\end{array}$ \\
\hline X1.1 & $\mathbf{0 . 8 3 6}$ & -0.471 & -0.454 & -0.451 \\
\hline X1.2 & $\mathbf{0 . 9 0 8}$ & -0.553 & -0.443 & -0.572 \\
\hline X1.3 & $\mathbf{0 . 8 8 0}$ & -0.558 & -0.465 & -0.592 \\
\hline X1.4 & $\mathbf{0 . 9 0 8}$ & -0.677 & -0.517 & -0.702 \\
\hline X1.5 & $\mathbf{0 . 7 6 7}$ & -0.628 & -0.450 & -0.498 \\
\hline X2.1 & -0.620 & 0.696 & 0.683 & $\mathbf{0 . 9 8 3}$ \\
\hline X2.2 & -0.628 & 0.700 & 0.687 & $\mathbf{0 . 9 1 6}$ \\
\hline X2.3 & -0.696 & 0.650 & 0.672 & $\mathbf{0 . 8 6 9}$ \\
\hline X2.4 & -0.573 & 0.685 & 0.636 & $\mathbf{0 . 9 6 5}$ \\
\hline X2.5 & -0.584 & 0.625 & 0.629 & $\mathbf{0 . 9 3 8}$ \\
\hline Y1.1 & -0.601 & $\mathbf{0 . 8 8 1}$ & 0.597 & 0.691 \\
\hline Y1.2 & -0.665 & $\mathbf{0 . 8 9 6}$ & 0.613 & 0.657 \\
\hline Y1.3 & -0.608 & $\mathbf{0 . 9 2 5}$ & 0.597 & 0.629 \\
\hline Y1.4 & -0.588 & $\mathbf{0 . 9 1 8}$ & 0.610 & 0.624 \\
\hline Y2.1 & -0.565 & 0.621 & $\mathbf{0 . 8 6 1}$ & 0.632 \\
\hline Y2.2 & -0.418 & 0.566 & $\mathbf{0 . 8 9 3}$ & 0.607 \\
\hline Y2.3 & -0.468 & 0.601 & $\mathbf{0 . 9 2 7}$ & 0.659 \\
\hline
\end{tabular}

Dapat dilihat bahwa korelasi variabel Ketidaknyamanan Promosi (X1) dengan indikatornya lebih tinggi dibandingkan Personal Seller (X2), Minat Beli Konsumen (Y1), dan Pemilihan Merek (Y2). Kemudian korelasi variabel Personal Seller (X2) indikatornya lebih tinggi dibandingkan Minat Beli Konsumen (Y1), Pemilihan Merek (Y2), dan Ketidaknyamanan Promosi (X1). Kemudian korelasi variabel Minat
Beli (Y1) indikatornya lebih tinggi dibandingkan Pemilihan Merek (Y2), Ketidaknyamanan Promosi (X1), dan Personal Seller (X2). Kemudian korelasi variabel Pemilihan Merek (Y2) indikatornya lebih tinggi dibandingkan Ketidaknyamanan Promosi (X1), Personal Seller (X2), dan Minat Beli Konsumen (Y1). Sehingga dapat dijelaskan bahwa seluruh indikator pada setiap variabel adalah valid. 


\section{Discriminant Validity dengan Menggunakan Akar Kuadrat Average Variance Extracted.}

\begin{tabular}{|c|c|c|}
\hline & $\begin{array}{l}\text { Average Variance } \\
\text { Extracted (AVE) }\end{array}$ & Akar (AVE) \\
\hline Ketidaknyamananpromosi & 0.742 & 0.861 \\
\hline Minatbeli & 0.819 & 0.905 \\
\hline Pemilihanmerek & 0.800 & 0.894 \\
\hline Personal Seller & 0.874 & 0.935 \\
\hline
\end{tabular}

Maka dapat dijelaskan bahwa akar AVE variabel Ketidaknyamanan Promosi, Personal Seller, Minat Beli, dan Pemilihan Merek, memiliki nilai
AVE masing-masing variabel nilainya lebih besar dari 0.50 , sehingga model dapat dikatakan baik.

\section{Composite Reliability}

Hasil Penelitian Reliabilitas Instrumen

\begin{tabular}{|l|c|c|}
\hline \multicolumn{1}{|c|}{ Variabel } & Cronbach's Alpha & Keterangan \\
\hline $\begin{array}{l}\text { Ketidaknyamanan } \\
\text { Promosi (X1) }\end{array}$ & 0,900 & Reliabel \\
\hline Personal Seller (X2) & 0,961 & Reliabel \\
\hline Minat Beli (Y1) & 0,915 & Reliabel \\
\hline Pemilihan Merek (Y2) & 0,951 & Reliabel \\
\hline
\end{tabular}

Hasil output composite reliability maupun cronbachs alpha untuk variabel Ketidaknyamanan Promosi,Personal Seller, Minat Beli, dan Pemilihan Merek semuanya diatas 0,70. Maka dapat disimpulkan bahwa variabel memiliki reliabilitas yang baik.

\section{Convergent Validity}

\section{Outer Loadings}

\begin{tabular}{|l|r|r|r|}
\hline & \multicolumn{1}{|l|}{$\begin{array}{l}\text { Original } \\
\text { Sample (O) }\end{array}$} & $\begin{array}{l}\text { T Statistics } \\
(|\mathrm{O} / \mathrm{STDEV}|)\end{array}$ & \multicolumn{1}{c|}{ P Values } \\
\hline X1.1 <- ketidaknyamananpromosi & 0.836 & 17.383 & 0.000 \\
\hline X1.2 <- ketidaknyamananpromosi & $\mathbf{0 . 9 0 8}$ & 34.855 & 0.000 \\
\hline X1.3 <- ketidaknyamananpromosi & 0.880 & 24.828 & 0.000 \\
\hline X1.4 <- ketidaknyamananpromosi & $\mathbf{0 . 9 0 8}$ & 51.584 & 0.000 \\
\hline X1.5 <- ketidaknyamananpromosi & 0.767 & 21.728 & 0.000 \\
\hline X2.1 <- personal seller & 0.983 & 265.188 & 0.000 \\
\hline X2.2 <- personal seller & 0.916 & 44.926 & 0.000 \\
\hline X2.3 <- personal seller & 0.869 & 34.557 & 0.000 \\
\hline X2.4 <- personal seller & $\mathbf{0 . 9 6 5}$ & 88.684 & 0.000 \\
\hline
\end{tabular}




\begin{tabular}{|l|l|l|l|}
\hline X2.5 <- personal seller & 0.938 & 49.352 & 0.000 \\
\hline Y1.1 <- minatbeli & 0.881 & 36.726 & 0.000 \\
\hline Y1.2 <- minatbeli & 0.896 & 45.607 & 0.000 \\
\hline Y1.3 <- minatbeli & $\mathbf{0 . 9 2 5}$ & 50.458 & 0.000 \\
\hline Y1.4 <- minatbeli & 0.918 & 49.236 & 0.000 \\
\hline Y2.1 <- pemilihanmerek & 0.861 & 22.589 & 0.000 \\
\hline Y2.2 <- pemilihanmerek & 0.893 & 30.178 & 0.000 \\
\hline Y2.3 <- pemilihanmerek & $\mathbf{0 . 9 2 7}$ & 55.650 & $\mathbf{0 . 0 0 0}$ \\
\hline
\end{tabular}

Hasil output telah memenuhi convergent validity karena loading factor berada diatas 0,50. Dari variabel Ketidaknyamanan Promosi (X1) indikator X1.2 dan X1.4 memiliki nilai outer loadings tertinggi dibandingkan indikator lain yaitu 0,908 , maka dapat dijelaskan bahwa indikator tersebutdapat merefleksikan variabel Ketidaknyamanan Promosi (X1). Dari variabel Personal Seller (X2) indikator X2.4memiliki nilai outer loadings tertinggi dibandingkan indikator lain yaitu 0,965 , maka dapat dijelaskan bahwa indikator tersebutdapat merefleksikan variabel Personal Seller (X2). Dari variabel Minat Beli (Y1) indikator Y1.3 memiliki nilai outer loadings tertinggi dibandingkan indikator lain yaitu 0,925 , maka dapat dijelaskan bahwa indikator tersebutdapat merefleksikan variabel Minat Beli (Y1). Dari variabel Pemilihan Merek (Y2) indikator Y2.3 memiliki nilai outer loadings tertinggi dibandingkan indikator lain yaitu 0,927 , maka dapat dijelaskan bahwa indikator tersebutdapat merefleksikan variabel Pemilihan Merek (Y2).

\section{Evaluasi Model Struktural atau Inner Model}

\subsection{R-square}

R-square

\begin{tabular}{|l|l|r|}
\hline & R Square & R Square Adjusted \\
\hline Minat Beli & 0.592 & 0.582 \\
\hline Pemilihan Merek & 0.446 & 0.440 \\
\hline
\end{tabular}

Berdasarkan hasil perhitungan Q2 dapat dilihat bahwa nilai 0.774 lebih besar dari 0 yang berarti bahwa model memiliki nilai predictive relevance yang baik (Ghozali, 2015). Ini berarti model yang diprediksi adalah sesuai. 


\section{Pengujian Hipotesis}

Path Coefficients

\begin{tabular}{|l|r|r|r|}
\hline & \multicolumn{2}{|l|}{$\begin{array}{l}\text { Original Sample } \\
\text { (O) }\end{array}$} & \multicolumn{2}{l|}{$\begin{array}{l}\text { T Statistics } \\
(\mid \text { O/STDEV|) }\end{array}$} & P Values \\
\hline $\begin{array}{l}\text { Ketidaknyamananpromosi } \\
\text {->minatbeli }\end{array}$ & -0.365 & 2.774 & 0.006 \\
\hline $\begin{array}{l}\text { Minatbeli - } \\
\text { >pemilihanmerek }\end{array}$ & 0.668 & 8.447 & 0.000 \\
\hline $\begin{array}{l}\text { personal seller - } \\
\text { >minatbeli }\end{array}$ & 0.477 & 3.444 & 0.001 \\
\hline
\end{tabular}

Pengaruh Ketidaknyamanan Promosi terhadap Minat Beli sebesar -0.365 menunjukkan bahwa Ketidaknyamanan Promosi berpengaruh negatif terhadap Minat Beli konsumen pada asuransi di Kota Denpasar, apabila Ketidaknyamanan Promosi meningkat maka Minat Beli akan mengalami penurunan sebesar -0.365 .

Pengaruh Personal Seller terhadap Minat Beli sebesar +0.477menunjukkan bahwa Personal Seller berpengaruh positif terhadap Minat Beli konsumen pada asuransi di Kota Denpasar, apabila Personal Seller meningkat maka Minat Beli akan mengalami peningkatan sebesar +0.477 .

Pengaruh Minat Beli terhadap Pemilihan Merek sebesar +0.668menunjukkan bahwa Minat Beli berpengaruh positif terhadap Pemilihan Merek pada asuransi di Kota Denpasar, apabila Minat Beli meningkat maka Pemilihan Merek akan mengalami peningkatan sebesar +0.668 .

\section{Pembahasan}

Pengaruh variabel Ketidaknyamanan Promosi (X1) terhadap Minat Beli Konsumen pada asuransi di PT. Prudential Life Assurance.

Pengaruh variabel Ketidaknyamanan Promosi (X1) terhadap Minat Beli Konsumen menunjukkan bahwa Ketidaknyamanan
Promosi berpengaruh negatif signifikan terhadap Minat Beli Konsumen terhadap asuransi di PT. Prudential Life Assurance. Ditunjukkan dengan koefisien sebesar 0.365 dan signifikan pada alpha 5 persen ( $p$ value $0,000 \leq 0,05)$. Artinya, semakin meningkat Ketidaknyamanan Promosi maka Minat Beli Konsumen terhadap asuransi di PT. Prudential Life Assurance juga akan semakin menurun. Berdasarkan hal tersebut maka H1 : Ketidaknyamanan Promosi berpengaruh negatif signifikan terhadap Minat Beli Konsumen terhadap produk asuransi di PT. Prudential Life Assurance diterima. Hasil ini juga didukung oleh penelitian yang dilakukan oleh Maulana \& Nurulfirdausi (2015), dimana semua responden yang disurvey menyatakan ketidaknyamanan akan telemarketing, karena mereka menyadari risiko data pribadi mereka dipertukarkan dengan pihak lain. Setiap calon pelanggan tentunya berharap agar mereka tidak mendapat konsekuensi negatif bila memberikan informasi pribadi ke telemarketer. Oleh karena itu, aspek ini juga perlu dipertimbangkan dalam praktik telemarketing.

Pengaruh variabel Personal Seller (X2) terhadap Minat Beli Konsumen pada asuransi di PT. Prudential Life Assurance. 
Pengujian hipotesis pada Pengaruh variabel Personal Seller (X2) terhadap Minat Beli menunjukkan bahwa Personal Seller berpengaruh positif signifikan terhadap Minat Beli Konsumen terhadap produk asuransi di PT. Prudential Life Assurance. Ditunjukkan dengan koefisien sebesar +0.477 dan signifikan pada alpha 5 persen ( $p$-value $0,000 \leq 0,05)$. Artinya, semakin menigkat Personal Seller yang dimiliki PT. Prudential Life Assurance maka Minat Beli Konsumen terhadap asuransi di PT. Prudential Life Assurance juga akan semakin tinggi. Berdasarkan hal tersebut maka $\mathrm{H} 2$ :Personal Seller berpengaruh positif signifikan terhadap Minat Beli Konsumen terhadap asuransi di PT. Prudential Life Assurance diterima. Hasil ini juga didukung oleh penelitian yang dilakukan oleh Bagus Noviantoro dan Yessy Artanti (2016), dimana Variabel penjualan pribadi (X1) mempunyai pengaruh yang positif terhadap keputusan pembelian polis asuransi jiwa prestigio di PT Zurich Topas Life yaitu sebesar 0,494. Irawan dan Karyani (2011) yangmenunjukkan bahwa penjualan pribadi memainkan peranan penting terhadap nasabah dalam keputusan menjadi nasabah asuransi. Hal ini diperkuat dengan teori yang dikemukakan oleh Kotler dan Keller (2007:318) penjualan pribadi memiliki beberapa aspek penting yaitu kemampuan tenaga penjual dalam mencari pelanggan dan melakukan kualifikasi, pendekatan pendahuluan, pendekatan, presentasi dan peragaan, mengatasi keberatan masalah, penutupan penjualan serta tindak lanjut dan pemeliharaan.
Pengaruh variabel Minat Beli(Y1) terhadap Pemilihan Merek pada asuransi di PT. Prudential Life Assurance.

Pengujian hipotesis pada Pengaruh variabel Minat Beli(Y1) terhadap Pemilihan Merek menunjukkan bahwa Minat Beliberpengaruh positif signifikan terhadap Pemilihan Merekterhadap asuransi di PT. Prudential Life Assurance. Ditunjukkan dengan koefisien sebesar +0.668dan signifikan pada alpha 5 persen ( $p$-value 0,000 $\leq 0,05)$. Artinya, semakin menigkat Minat BeliKonsumen pada PT. Prudential Life Assurance maka Pemilihan Merek terhadap asuransi di PT. Prudential Life Assurance juga akan semakin tinggi. Berdasarkan hal tersebut maka H3 :Minat Beliberpengaruh positif signifikan terhadap Pemilihan Merek terhadap asuransi di PT. Prudential Life Assurance diterima. Hasil ini juga didukung oleh penelitian yang dilakukan Abdul Hakim (2008) yang menyatakan bahwa yaitu pemilihanmerek mempengaruhi keputusan pembelian. Menurut Berkowitz, et.all dalam Rahman (2009) terdapat empat faktor yang mempengaruhi keputusan dalam pemilihan merek, salah satu faktor terpenting adalah faktor psikologis. Satu perangkat proses psikologis berkombinasi dengan karakteristik konsumen tertentu untuk menghasilkan proses keputusan terhadap pemilihan merek. Psikologis konsumen secara fundamental merupakan pengaruh utama bagaimana tanggapan konsumen dan bereaksi terhadap berbagai rangsangan pemasaran. 


\section{Kesimpulan}

\section{Kesimpulan}

Berdasarkan hasil penelitian dan pembahasan diatas, maka dapat ditarik beberapa simpulan sebagai berikut:

a. Ketidaknyamanan Promosi berpengaruh negatif signifikan terhadap Minat Beli Konsumen pada asuransi di PT. Prudential Life Assurance, hal ini diperoleh dari koefisien sebesar -0.365 dan signifikan pada alpha 5 persen ( $p$ value $0,000 \leq 0,05$ ).

b. Personal Seller berpengaruh positif signifikan terhadap Minat Beli Konsumen pada asuransi di PT. Prudential Life Assurance, hal ini diperoleh dari koefisien sebesar +0.477dan signifikan pada alpha 5 persen ( $p$-value $0,000 \leq 0,05$ ).

c. Minat BeliKonsumen berpengaruh positif signifikan terhadap Pemilihan Merek pada asuransi di PT. Prudential Life Assurance, hal ini diperoleh dari koefisien sebesar +0.668 dan signifikan pada alpha 5 persen ( $p$-value $0,000 \leq 0,05$ ).

\section{REFRENSI}

Abdillah, W. dan Jogiyanto, H. M. (2009). Konsep dan Aplikasi PLS (Partial Least Square) Untuk Penelitian Empiris. Yogyakarta: Badan Penerbit Fakultas Ekonomi.

Adebisi, S and Babatunde Bayode. 2011. "Strategic Influence of Promotional Mix On Organisation Sale Turnover
In The Face of Strong Competitors", Busines Intelligence Journal.

Aryanto, Doddy. 2008. Personal Selling dan Keputusan Membeli Nasabah (Studi Korelasional Personal Selling Asuransi Kerugian Terhadap Keputusan Membeli Nasabah di PT. Fadent Mahkota Sahid Medan). Jurnal, Universitas Sumatra Utara, Medan.

Bagus Noviantoro Dan Yessy Artanti. 2016. Pengaruh Penjualan Pribadi Dan Citra Merek Terhadap Keputusan Pembelian Polis Asuransi Jiwa Prestigio. Jurnal Bisnis dan Manajemen, 1411 - 9366.

Dedi Wahyudi dan Rumby T. Aruan. 2013. Analisis Personal Selling Pada

PT. Prudential Life Assurance Medan. Jurnal Bisnis Administrasi, Volume 02, Nomor 02, 2013, 21-29.

Engkos, Ridwan dan Achmad Kuncoro. Cara Menggunakan dan Memaknai Path Analysis. Alfabeta: Bandung, 2013.

Ghozali, Imam., 2014, Structural Equation Modeling, Metode Alternatif dengan Partial Least Square (PLS), Edisi 4, Semarang: Badan Penerbit Universitas Diponegoro.

Ghozali dan H. Latan, 2015. Partial Least Squares_: Konsep, Teknik dan Aplikasi Menggunakan Smart PLS 3.0, Edisi 2. Universitas Diponegoro.

Julius R. Latumaerissa. 2011. Bank dan Lembaga Keuangan Lain. Jakarta. Salemba Empat. 
Kotler dan Amstrong. 2006. Prinsip Prinsip Pemasaran, Jilid 2.

Jakarta. Erlangga.

Lee, M, 2004. Attitudes toward direct marketing, privacy, environment and trust: Taiwan vs US. International Journal of Commerce and Management.14(1):

1-18.

Louisa Ha, E.Lincoln James. Determinats of Consumer Responses to Direct Marketing Media. Journal of Promotion Management.2008 : 17-34

Margono, S. 2010. Metode Penelitian Pendidikan. Jakarta. Rineka Cipta

Ralph W.Giacobbe, Donald W.Jackson Jr, Lawrence A.Crosby, Caludia M.Bridges. 2013. A Contingency Approach to Adaptive Selling Behavior and Sales Performance: Selling Situations and Salesperson Characteristics. Journal of Personal Selling and Sales Management.: 115 142

Robert W.Shoemaker, Richard Staelin, Joseph B.Kadaen, F.Robert. Relation of Brand Choice to Purchase Frequency. Journal of Marketing Research. 2015 : 458-468

Rut Rismanta Silalahi1, Witanti Prihatiningsih dan Ratu Laura M B P. 2018. Hubungan Antara Komunikasi Telemarketing Asuransi Dengan Sikap Calon Pelanggan Terhadap Telemarketer. Journal Of Communication Studies Vol 3 No 2.

Sholihin, M. dan Ratmono, D. 2013. Analisis SEM-PLS Warp PLS 3.0. Penerbit ANDI, Yogyakarta.
Sujarweni, V. Wiratna. 2014. Metode Penelitian:Lengkap, Praktis dan Mudah Dipahami. Yogyakarta. Pustaka Baru Press.

Tjiptono, F. 2011. Manajemen dan Stratregi Merek, Seri Manajemen Merek 01.

Yogyakarta. Andi Offset.

Xuehua Wang, Hean Tat Keh. Consumer susceptibility to Cross-Selling Persuation : The Roles of Selfcontrual and Interpersonal Harmony. Journal of Retailing and Consumer Services. 2017: 177-184 